\title{
Effect of decreasing acidity on the extractability of inorganic soil phosphorus
}

\author{
HELINÄ HARTIKAINEN
}

Department of Agricultural Chemistry, University of Helsinki, 00710 Helsinki 71

\begin{abstract}
The extractability of $\mathrm{P}$ by the water and anion exchange resin methods and reactions of soil inorganic $\mathrm{P}$ were investigated with seven acid mineral soil samples incubated with $\mathrm{KOH}$ solutions of various concentrations. The results were compared with the analytical data obtained from three soil samples incubated in a prolonged liming experiment.

The resin extraction method proved more effective than the water extraction method. The amounts of $\mathrm{P}$ desorbed by both methods seemed to increase exponentially as the $\mathrm{pH}$ in the soil suspensions rose. The factors involved were discussed.

On the basis of fractionation analyses $\mathrm{P}$ reacting to changes in the $\mathrm{pH}$ and participating in desorption processes was supposed to originate from secondary $\mathrm{NH}_{4} \mathrm{~F}$ and $\mathrm{NaOH}$ soluble reserves. In general, as the acidity decreased $\mathrm{NH}_{4} \mathrm{~F}-\mathrm{P}$ increased at the expense of $\mathrm{NaOH}$-P. In heavily limed gyttja soil also $\mathrm{H}_{2} \mathrm{SO}_{4}-\mathrm{P}$ increased. This was possibly induced by the precipitation of mobilized $\mathrm{P}$ as a $\mathrm{Ca}$ compound. The significance of $\mathrm{pH}$ in the extractability of soil $\mathbf{P}$ seemed somewhat to lessen as the amount of secondary $\mathrm{P}$ increased.

The results were in accordance with the conception that liming improves the availability of inorganic $\mathrm{P}$ to plants and reduces the need for $\mathrm{P}$ fertilization. However, increasing of the soil $\mathrm{pH}$ involves the risk that $\mathrm{P}$ is more easily desorbed to the recipient water by the eroded soil material carried into the watercourse. Therefore, intensive liming is not recommendable close to the shoreline. Further, it should be taken into account that liming of lakes may also result in eutrophication as desorption of sedimentary inorganic $\mathbf{P}$ is enhanced.
\end{abstract}

\section{Introduction}

The effective retention of phosphorus by acid Finnish soils decreases the availability of phosphorus to plants and results in a continuous accumulation of fertilizer phosphorus in the surface soils. The improvement of the utilization of phosphorus is of importance not only in plant production but also in protection of waters. Although the leaching of phosphorus normally is insignificant, considerable amounts of phosphorus bound by eroded soil material may be carried into waters. The possible eutrophication risk due to this phosphorus is dependent on the properties of soil and the conditions in the recipient water (HARTIKAINEN 1979). However, the eroded soil material being carried into watercourses always causes potential loading. This means that environmental conditions in the water may alter, resulting in mobilization of certain phosphorus reserves from the sedimented soil material to the overlying water. 
The purpose of this study was to investigate the effect of acidity on the extractability of soil phosphorus. The results were considered to elucidate not only the influence of liming on the availability of phosphorus in cultivated soils but also the dependence between $\mathrm{pH}$ and the liability of eroded soil material and lake sediments to desorb phosphorus.

\section{Materials and methods}

The experiment was carried out with seven acid mineral soil samples representing the plough layer: two silt (samples 1 and 2), two silty clay ( 3 and 4 ) and three heavy clay soils $(5-7)$. In addition, comparative studies were made with sand (8), heavy clay (9) and gyttja clay soil samples (10), one of each, incubated in an earlier experiment at $20^{\circ} \mathrm{C}$ for more than half a year with and without liming. The sand and heavy clay soil were limed with $0.375 \%$ of $\mathrm{CaCO}_{3}$ and the gyttja clay soil with $0.375-3.00 \%$ of $\mathrm{CaCO}_{3}$. Some characteristics of the soil samples are listed in Table 1.

Soil $\mathrm{pH}$ was measured by a Beckman $\mathrm{pH}$-meter in a $0.01 \mathrm{M} \mathrm{CaCl}_{2}$ suspension in the ratio of 1 to 2.5. The content of organic carbon in the samples was determined by a modified WALKLEY and BLACK wet combustion method (GRAHAM 1948). When calculating the analytical results, it was assumed that $80 \%$ of $\mathrm{C}$ in the soils was covered. The amorphous aluminium and iron were extracted by $0.3 \mathrm{M}$ acid ammonium oxalate (TAMM 1922) in the ratio of soil to solution of 1 to 20 $(\mathrm{w} / \mathrm{v})$. After the organic matter in the extract was destructed by ignition, $\mathrm{Al}$ was determined by a modified Aluminon method (McLEAN 1965) and $\mathrm{Fe}$ by the sulfosalicylic acid procedure (KOUTLER-ANDERSSON 1953). Exchangeable aluminium was extracted by four portions of $1 \mathrm{M} \mathrm{KCl}$ in the ratio of soil to solution of 1 to $5(\mathrm{w} / \mathrm{v})$. The particle size composition of the mineral material in the soils was determined by a pipette method (ELONEN 1971).

The effect of increasing $\mathrm{pH}$ on the desorption of phosphorus was studied by water extraction and by anion exchange resin extraction. Reactions of soil phosphorus were investigated by a modified CHANG and JACKSON (1957) fractionation

Table 1. Characteristics of experimental soils.

\begin{tabular}{|c|c|c|c|c|c|c|c|c|c|c|}
\hline \multirow{3}{*}{$\begin{array}{l}\text { Soil } \\
\text { No }\end{array}$} & \multirow{3}{*}{$\begin{array}{c}\text { Clay } \\
\%\end{array}$} & \multirow[b]{3}{*}{$\mathrm{pH}$} & \multirow{3}{*}{$\begin{array}{l}\text { Org. C } \% \\
\text { of D.M. }\end{array}$} & \multirow{2}{*}{\multicolumn{4}{|c|}{$\begin{array}{l}\mathrm{P}(\mathrm{ppm}) \text { extracted } \\
\text { sequentially by }\end{array}$}} & \multirow{3}{*}{$\begin{array}{l}\text { Exch. } \\
\mathrm{Al} \\
\text { ppm }\end{array}$} & \multicolumn{2}{|c|}{ Oxalate extr. } \\
\hline & & & & & & & & & Al & $\mathrm{Fe}$ \\
\hline & & & & $\mathrm{NH}_{4} \mathrm{Cl}$ & $\mathrm{NH}_{4} \mathrm{~F}$ & $\mathrm{NaOH}$ & $\mathrm{H}_{2} \mathrm{SO}_{4}$ & & ppm & ppm \\
\hline 1 & 15 & 4.6 & 3.4 & 2.3 & 159 & 145 & 91 & 134 & 6175 & 5050 \\
\hline 2 & 15 & 4.7 & 4.1 & 1.3 & 153 & 138 & 110 & 122 & 5720 & 5528 \\
\hline 3 & 34 & 4.5 & 7.7 & 2.9 & 73 & 108 & 155 & 116 & 3290 & 4663 \\
\hline 4 & 44 & 4.3 & 3.2 & 2.1 & 134 & 530 & 188 & 181 & 6750 & 16250 \\
\hline 5 & 61 & 4.8 & 6.5 & 1.0 & 89 & 427 & 230 & 67 & 6550 & 14583 \\
\hline 6 & 65 & 4.6 & 6.6 & 1.3 & 147 & 384 & 155 & 183 & 6900 & 12368 \\
\hline 7 & 84 & 4.8 & 6.7 & 1.2 & 66 & 171 & 71 & 72 & 5285 & 7500 \\
\hline 8 & 14 & 5.9 & 2.9 & 10.3 & 250 & 250 & 260 & n.d. & n.d. & n.d. \\
\hline 9 & 78 & 5.6 & 1.0 & 0.8 & 19 & 78 & 292 & n.d. & n.d. & n.d. \\
\hline 10 & 59 & 3.5 & 3.1 & 3.3 & 33 & 388 & 145 & n.d. & n.d. & n.d. \\
\hline
\end{tabular}


procedure. The various extracts were analysed for phosphorus by a molybdenum blue method modified by KAILA (1955).

Addition of $\mathrm{CaCO}_{3}$ to the soil does not immediately decrease the soil acidity, only after incubation. Therefore, it is possible that microbiological processes and organic matter affect the extractability of soil nutrients. In order to avoid this, the $\mathrm{pH}$ was quickly raised by $\mathrm{KOH}$ solutions in this experiment. Further, the slow dissolution of $\mathrm{CaCO}_{3}$ was assumed possibly to cause some experimental errors, because free $\mathrm{CaCO}_{3}$ is found to disturb the fractionation analysis of phosphorus (WILLIAMS et al. 1971).

On the other hand, the rate-limiting step in exchange reactions often is the ion diffusion to or from the colloid surface. Because the ion movement was not speeded up in this experiment by shaking the samples, it is not certain that the soil acidity was completely attacked in the $\mathrm{KOH}$ treatments. Therefore it is more accurate to deal with $\mathrm{pH}$ in the soil suspension instead of the soil $\mathrm{pH}$.

One gram of soil weighed into a centrifuge tube was moistened with one $\mathrm{ml}$ of $\mathrm{KOH}$ solution $(0.01-0.4 \mathrm{M})$ and incubated over night. The control sample was incubated with one $\mathrm{ml}$ of distilled water. In water extraction the incubated samples were shaken for one hour with $50 \mathrm{ml}$ of distilled water and centrifuged. The supernatant solutions were filtered through a $0.2 \mu \mathrm{m}$ membrane filter. Resin extraction was performed by the method described by AURA (1978 a), using one gram of soil, $100 \mathrm{ml}$ of distilled water and $2 \mathrm{~g}$ of anion-exchange resin (Dowex 21-K, 16-20 mesh, Cl-form). The extraction time was one hour. The extracts were analysed for phosphorus by the ascorbic acid method (ANON. 1969).

In order to investigate changes in the $\mathrm{pH}$ caused by the base treatment, $10 \mathrm{~g}$ of soil was moistened with $10 \mathrm{ml}$ of $\mathrm{KOH}$ solution $(0.01-0.4 \mathrm{M})$ or with $10 \mathrm{ml}$ of distilled water. To the samples incubated over night $25 \mathrm{ml}$ of $0.01 \mathrm{M} \mathrm{CaCl}_{2}$ solution was added and the $\mathrm{pH}$ in the suspension was measured after they were allowed to stand for four hours.

The tests were carried out with four replicates, excluding the $\mathrm{pH}$ measurements performed with two replicates.

\section{Results}

The treatment of the various soils with $\mathrm{KOH}$ solutions affected the $\mathrm{pH}$ in the soil suspensions to various degrees (see Figures $\mathrm{l}$ and 2). After incubation with 0.4 $\mathrm{M} \mathrm{KOH}$ solution the $\mathrm{pH}$ rose in some suspensions much over 9, while in one sample it was only 7.7. Because Finnish soils do not involve so hight $\mathrm{pH}$ values, discussions were concentrated mainly on the results from samples with $\mathrm{pH}$ below 7 .

Figures 1 and 2 show that the amounts of phosphorus desorbed by water extraction as well as by resin extraction increased with decreasing acidity. In the above figures the points over $\mathrm{pH} 7$ are joined together by dotted lines. On the other hand, the results obtained in the fractionation analyses (not presented) demontrated that the treatments with $\mathrm{KOH}$ solutions of various concentrations caused no statistically significant changes in the total quantities of fractionated inorganic phosphorus in a given soil. But with increasing $\mathrm{pH}$ the base soluble phosphorus reserves tended to decrease at the same time as the fluoride extractable fraction became greater. The 


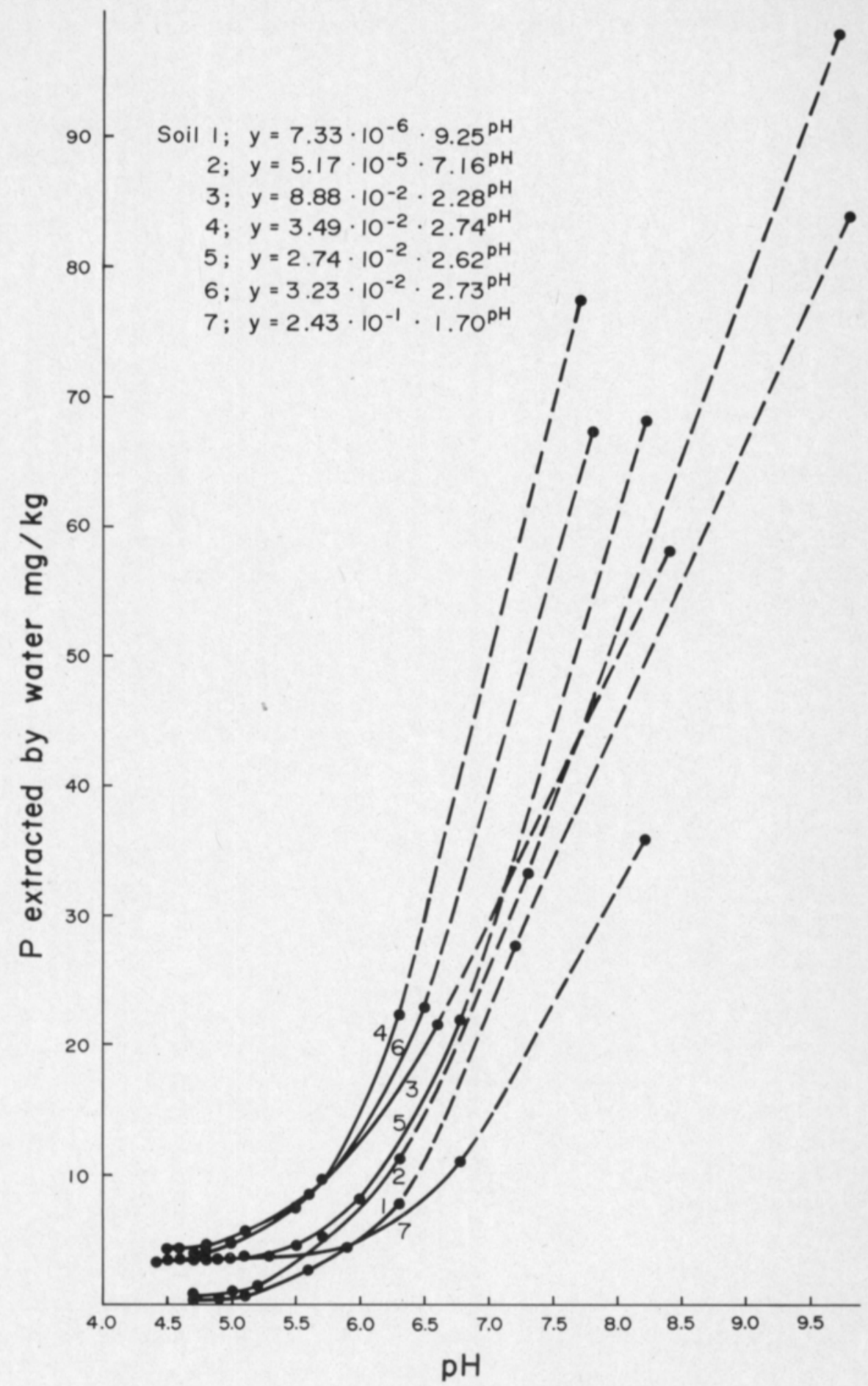

Fig. 1. Soil phosphorus desorbed by water extraction at different $\mathrm{pH}$ levels. 
acid soluble reserves seemed unattacked. The $\mathrm{NH}_{4} \mathrm{Cl}-\mathrm{P}$ markedly rose only at very high $\mathrm{pH}$ values.

In some cases, in water or resin extraction, the desorption of phosphorus from a given soil at different $\mathrm{pH}$ levels seemed to be connected with the amount of the fluoride or/and base soluble phosphorus: desorption was intensified with increasing

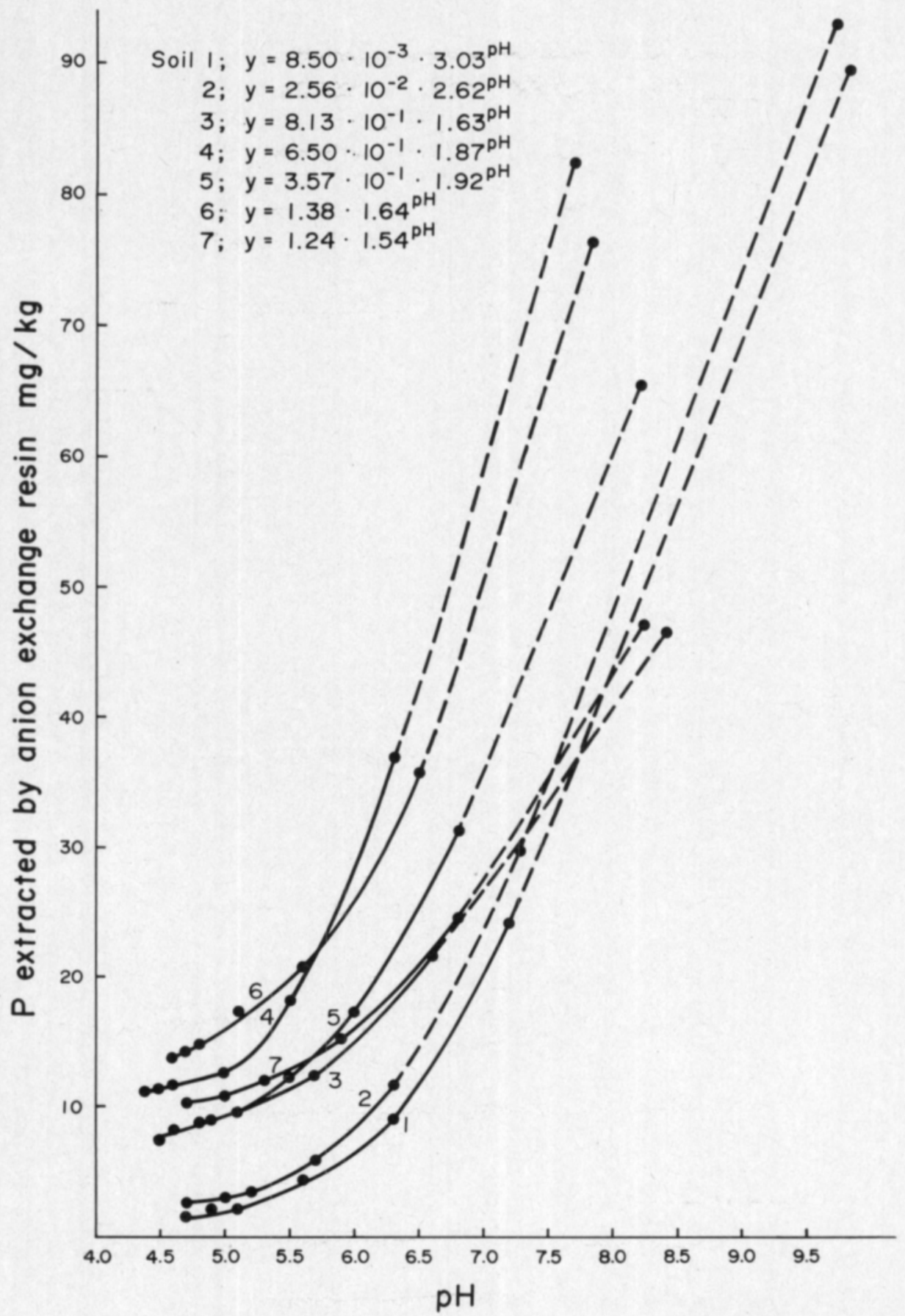

Fig. 2. Soil phosphorus desorbed by anion exchange resin extraction at different $\mathrm{pH}$ levels. 
$\mathrm{NH}_{4} \mathrm{~F}-\mathrm{P}$ fraction and decreasing $\mathrm{NaOH}-\mathrm{P}$ fraction. However, when calculating partial correlation coefficients between the phosphorus desorbed and these fractions by eliminating the influence of the $\mathrm{pH}$, a statistically significant positive dependence between the water soluble and $\mathrm{NH}_{4} \mathrm{~F}$ extractable phosphorus was found only in samples 5 and 7. The corresponding dependence in resin extraction was found in samples 3 and 5. Thus it can be concluded that the $\mathrm{pH}$ alone is of greater importance on the extractability of soil phosphorus than the distribution of secondary phosphorus in various chemical fractions. This supposition is supported by the fact that neither the decrease in $\mathrm{NaOH}-\mathrm{P}$ nor the increase in $\mathrm{NH}_{4} \mathrm{~F}-\mathrm{P}$, respectively, quantitatively corresponded to the intensifield desorption observed in water and resin extraction.

Desorption followed the exponential equation $y=a b x$, where $y$ is desorbed $P$ $\mathrm{mg} / \mathrm{kg}$ soil, $\mathbf{x}$ is $\mathrm{pH}$, $\mathrm{a}$ and $\mathrm{b}$ constants. However, the equations presented in Figures 1 and 2 give evidence that the factors $a$ and $b$ are dependent on each other. When $b$ increases, it seems as if a would decrease logarithmically.

When comparing the curves in Figures 1 and 2, it can be seen that at low $\mathrm{pH}$ values desorption from various soils differed relatively more in resin extraction than in water extraction. Further, the equations calculated show that the water soluble phosphorus is more strongly dependent on $\mathrm{pH}$ than the resin extractable phosphorus. This means that, although at low $\mathrm{pH}$ level the extraction of phosphorus by the water treatment is not as effective as that by the resin treatment, at higher $\mathrm{pH}$ values the differences between these methods tend to become equalized.

For the sake of comparison, the extractability of phosphorus was investigated also with three soil samples incubated in a prolonged experiment with and without $\mathrm{CaCO}_{3}$. The results are presented in Table 2. In the sand soil sample (8) liming doubled the already exceptionally high $\mathrm{NH}_{4} \mathrm{Cl}$ soluble fraction. The $\mathrm{NaOH}-\mathrm{P}$ was markedly decreased, but the other fractions seemed to remain unchanged. In the heavy clay (9) and gyttja clay soil samples $(10)$ the $\mathrm{NH}_{4} \mathrm{~F}-\mathrm{P}$ significantly rose at the expense of the $\mathrm{NaOH}-\mathrm{P}$ as the $\mathrm{pH}$ increased. Further, it was interesting to observe that in the gyttja clay soil also the $\mathrm{H}_{2} \mathrm{SO}_{4}-\mathrm{P}$ distinctly tended to increase with intensified liming. The $\mathrm{NH}_{4} \mathrm{Cl}-\mathrm{P}$ likewise was somewhat augmented when the $\mathrm{pH}$ rose to 6.9 .

Table 2. $\mathrm{pH}$, water and resin extractable $\mathrm{P}$ (ppm) in three soils incubated with and without liming.

\begin{tabular}{lccccccccc}
\hline $\begin{array}{l}\text { Lime } \\
\text { applied }\end{array}$ & \multicolumn{4}{c}{$\begin{array}{c}\text { Soil 8 } \\
\text { P extr. by }\end{array}$} & pH & water & resin & pH & \multicolumn{2}{c}{$\begin{array}{c}\text { Poil 9 } \\
\text { water }\end{array}$} & resin & pH & \multicolumn{2}{c}{$\begin{array}{c}\text { Soil 10 } \\
\text { water }\end{array}$} & resin \\
\hline 0 & 5.9 & 14.2 & 17.2 & 5.6 & 0.8 & 1.5 & 3.5 & 0.4 & 0.4 \\
0.375 & 6.9 & 14.9 & 22.8 & 6.9 & 1.9 & 3.0 & 3.7 & 0.4 & 0.2 \\
0.75 & - & - & - & - & - & - & 3.8 & 0.5 & 0.2 \\
1.50 & - & - & - & - & - & - & 4.8 & 0.6 & 0.9 \\
3.00 & - & - & - & - & - & - & 6.9 & 2.5 & 8.6 \\
\hline
\end{tabular}

\section{Discussion}

Numerous field and pot experiments have proved that judicious liming of acid soils improves the uptake of phosphorus by plants (e.g. BOHNE 1949, GERICKE 
1951, FÜLEKY 1978). Because it improves general growing conditions for plants, there is disagreement about the interpretation of experimental results.

Even if no proper liming medium was used in the first experiment made in the present study, the data obtained imply that the improvement of the availability of phosphorus may be associated with the intensified desorption due to the increasing $\mathrm{pH}$. The water and resin extractions used in pot experiments did illustrate quite well the phosphorus uptake by plants from Finnish soils (AURA 1978 a). Furthermore, according to KAILA (1965), a relatively heavy liming does not necessarily enhance the mineralization of organic phosphorus in soils.

At all $\mathrm{pH}$ levels $(<7)$ more phosphorus was extracted by the resin treatment than by the water treatment. This is of couse due to the fact that in water extraction a certain equilibrium corresponding to the intensity factor of soil phosphorus status at the $\mathrm{pH}$ level involved will be achieved with progressing desorption. The resin, on the other hand, maintains a low phosphorus concentration in the solution by absorbing phosphorus released, enchancing desorption. It is not possible to attain a complete equilibrium status within one hour, but an equally long extraction time was chosen for both treatments. Desorption by the anion exchange resin is found to be in a linear dependence on the square root of the extraction time (COOKE 1966, AURA 1978 b), but e.g. in the study published by STÅHLBERG (1980) the prolongation of the extraction time from one hour to two hours hardly affected the quantity of phosphorus extracted by salt solution.

When the term a in the desorption equations (Figure 1 and 2) increases, the term $\mathrm{b}$ decreases, but relatively slowly. In practice this means that the influence of the $\mathrm{pH}$ on desorption is somewhat weakened as the value of the term a increases. On the basis of the fractionation analyses the term a can be concluded to be connected with the amount of secondary phosphorus in soils. The empirical Freundlich adsorption isotherm implies that the energy of adsorption decreases logarithmically as the fraction of surface covered increases. Because a decrease in the adsorption energy signifies an intensified desorption tendency, the phosphorus desorption from soil can be presumed to become greater as the coverage of sorption surface increases. This again would mean that also the content of sorptive components would be included in the term a. So, this factor could, to some extent, indicate the magnitude of adsorption energy or, inversely, the desorption tendency.

If the term a is a characteristic of a given soil, it means that, as the amount of secondary phosphorus in this soil increases, its sorption strength is reduced, i.e. its desorption tendency is enhanced. On the basis of what has been stated above it can be supposed that in this case the significance of $\mathrm{pH}$ in desorption tends to lessen, but relatively slowly.

Desorption by water extraction seemed to be more $\mathrm{pH}$-dependent than that by resin extraction. As the acidity decreased the portion of water soluble phosphorus from the resin extractable quantities regularly increased. This likely resulted from the fact that in water extraction the considerable increase in $\mathrm{OH}^{-}$ion concentration owing to the rising $\mathrm{pH}$ sharply reduces the ability of phosphate ions to compete for sorption components. In resin extraction the significance of $\mathrm{OH}^{-}$ions as exchangers of soil phosphate is reduced by their adsorption onto the resin surface. This allows further to conclude that the quantity of resin may be a critical factor in this method.

In a previous study (HARTIKAINEN 1979) water tended to extract phosphorus 
the more the higher the soil $\mathrm{pH}$ was $\left(\mathrm{r}=0.72^{* * *}, \mathrm{n}=24\right)$. According to the same paper also the EPC-values in a selected soil material tended to increase when the soil $\mathrm{pH}$ rose. EPC (equilibrium phosphate concentration) is a term expressing the phosphate concentration in water where no net phosphate exchange occurs upon addition of the sample to the aqueous system. In larger materials including very different soil samples, a linear correlation between the phosphorus desorption by water or resin extraction and soil pH may remain quite low (cf. SIPPOLA and JANSSON 1979). This is possibly due to the fact that the influence of $\mathrm{pH}$ is connected with the quantities of secondary phosphorus and corresponding sorption components.

In spite of some unspecificity in the extraction reagents, the modified CHANG and JACKSON fractionation method is quite useful for determination of differently reacting phosphorus reserves (HARTIKAINEN 1979). The changes in distribution of secondary phosphorus in various fractions were the same with the $\mathrm{KOH}$ treatments as with the liming in the incubation experiment made by KAILA (1965). The decrease in the $\mathrm{NaOH}-\mathrm{P}$ supposed to represent phosphorus bound by iron is in agreement with the fact that the maximum ability of iron to precipitate phosphate is at a lower $\mathrm{pH}$ level than that of aluminium (GAARDER 1934).

The solubility diagrams for $\mathrm{P}$ compounds developed by LINDSAY and MORENO (1960) show the solubilities of strengite $\left[\mathrm{Fe}(\mathrm{OH})_{2} \mathrm{H}_{2} \mathrm{PO}_{4}\right]$ and variskite $\left[\mathrm{Al}(\mathrm{OH})_{2} \mathrm{H}_{2} \mathrm{PO}_{4}\right]$ to increase parallelly as the acidity decreases. However, according to the conception prevailing today, the phosphorus retention by acid soils does not occur by precipitation as $\mathrm{Fe}$ and $\mathrm{Al}$ compounds difficult to dissolve. The phosphate is considered to be adsorbed onto hydrated metal oxides by so called ligand exchange, i.e. by replacing $\mathrm{H}_{2} \mathrm{O}$-groups of $\mathrm{OH}^{-}$ions bound with a coordination bond to the metal atom (e.g. PARKS 1965, HINGSTON et al. 1967). It is, however, obvious that with progressively increasing $\mathrm{pH}$ the desorption of phosphorus bound also by the ligand exchange mechanism onto the surface of the iron oxide enhances earlier than that of phosphorus bound analogously by aluminium oxide. The hydrated $\mathrm{Fe}^{3}+$ ion is a stronger acid than the corresponding $\mathrm{Al}^{3}+$ ion (HUNT 1963, ref. MORTLAND 1968). So, as the $\mathrm{pH}$ increases the $\mathrm{Al}$ ion is surrounded by a greater number of undissociated $\mathrm{H}_{2} \mathrm{O}$-groups found to be more easily than $\mathrm{OH}^{-}$ions replaced by phosphate ion (RAJAN et al. 1974). In other words, the ability of iron to retain phosphate is reduced at a lower $\mathrm{pH}$ than that of aluminium.

The results obtained in the fractionation analyses also indicate that, although the $\mathrm{KOH}$ treatments possibly altered quantities of phosphorus bound by various sorption components, the extractability of phosphorus in both $\mathrm{NH}_{4} \mathrm{~F}$ and $\mathrm{NaOH}$ soluble fractions was simultaneously improved. $\mathrm{OH}^{-}$ions obviously begin to compete with phosphate ions for sorption components as the $\mathrm{pH}$ increases.

Even if the samples incubated with $\mathrm{CaCO}_{3}$ behaved similarly as the ones used in the $\mathrm{KOH}$ experiment, the results obtained in the fractionation analysis of the gyttja clay soil leads to suppose that the quality of the base applied to soil may be of importance in reactions of phosphorus. An increase in $\mathrm{H}_{2} \mathrm{SO}_{4}-\mathrm{P}$ with intensified liming implies that at least heavily limed soils may contain secondary phosphorus bound by various mechanisms. When the solubility of phosphorus bound by iron compounds increases, part of the dissolved phosphorus is possibly retained by $\mathrm{CaCO}_{3}$ which is supposed to be a sorptive component e.g. in calcareous sediments (LI et al. 1972). However, there is some evidence that the carbonate precipitates are 
quite weak as phosphorus retention agents (COLE et al. 1953, SHUKLA et al. 1971). It is more probable that, as the Ca concentration increases, phosphorus begins to precipitate as a $\mathrm{Ca}$ compound. This assumption is supported by the fact that, when the $\mathrm{pH}$ in the soil suspensions was raised to very high levels with $\mathrm{KOH}$, the quantities of $\mathrm{H}_{2} \mathrm{SO}_{4}$-P seemed not to be affected.

The soil samples contained moderate amounts of exchangeable aluminium (Table 1). Its polymerization to hydroxide compound due to the $\mathrm{KOH}$ addition possibly resulted in some increase in sorptive components. Because no decrease in phosphorus desorption was found at any $\mathrm{pH}$ level, it is probable that the influence of increasing quantity of sorptive agents was of minor importance and furthermore, counteracted by enhanced desorption. If this is true, the intensification of the mobilization measured is in certain $\mathrm{pH}$ range to some degree a net increase in the extractability. It is interesting that DICKSON (1979) found a rapid phosphorus precipitation, especially in the $\mathrm{pH}$ range $5-6$, when a humus-poor acid lake water sample containing dissolved aluminium was limed.

The results are in accordance with the conception that smaller doses of phosphorus fertilizers are needed in soils with high $\mathrm{pH}$ values than in soils with low $\mathrm{pH}$. Although a judicious liming improves general conditions for plant growth and likely the utilization of phosphorus, it is not recommended to lime fields in the immediate vicinity of lakes. The eutrophication risk induced by eroded soil material being carried into waters becomes greater as the $\mathrm{pH}$ in the soil increases. However, the liming hardly contributes to the leaching of phosphorus into drainage or ground water, because the phosphorus possibly leached below the plough layer is resorbed by active oxides in the subsoil.

Further, the results imply that an increase in phosphorus concentration in waters owing to the liming of lakes (e.g. DICKSON 1979) may be caused not only by accelerated mineralization of organic phosphorus compounds but also by improved desorption of certain inorganic sedimentary phosphorus reserves. Basing on this, a cautious stand ought to be taken in the intensive liming of lakes.

Acknowledgement. The author wishes to thank the Maj and Tor Nessling Foundation for supporting this study financially.

\section{References}

ANON. 1969. Juoma- ja talousveden tutkimusmenetelmät. Elintarviketutkijain Seura. 169 p. Helsinki.

AURA, E. 1978 a. Determination of available soil phosphorus by chemical methods. J. Scient. Agric. Soc. Finl. S0: $305-316$.

- 1978 b. Phosphate desorption from soil in anion-exchange resin extraction. J. Scient. Agric. Soc. Finl. 50: $335-345$.

BOHNE, H. 1949. Laboratoriumsversuche zur Frage der Mobilisierung der Bodenphosphorsäure durch Kalk auf sauren Böden. Z. Pfl.ern. Düng. Bodenk. 43: 37-55.

CHANG, S. C. \& JACKSON, M. L. 1957. Fractionation of phosphorus. Soil Sci. 84: 133-144.

COLE, C. V., OLSEN, S. R. \& SCOTT, C. O. 1953. The nature of phosphate sorption by calcium carbonate. Soil Sci. Soc. Amer. Proc. 17: 352-356.

COOKE, I. J. 1966. A kinetic approach to the description of soil phosphate status. J. Soil Sci. 17: 56-64.

DICKSON, W. 1979. Kalkning av sjöar. J. R. Swed. Acad. Agric. For. Suppl. 13: 38-48.

ELONEN, P. 1971. Particle-size analysis of soil. Acta Agr. Fenn. 122: 1-122. 
FÛLLEKY, Gy. 1978. Available phosphorus content of soil affected by $\mathrm{P}$ fertilization and its change in time. Commun. Soil Sci. Pl. Anal. 4: 851-863.

GAARDER, T. 1934. Fosforsyrens binding og frigjøring i jorden. Nord. Jordbr.forskn. 1934: 197-216.

GERICKE, S. 1951. Beziehungen zwischen den Wachstumsfaktoren Kalk und Phosphorsäure. Z. Acker- u. Pfl.bau 93: 141-168.

GRAHAM, E. R. 1948. Determination of soil organic matter by means of a photoelectric colorimeter. Soil Sci. 65: $181-183$.

HARTIKAINEN, H. 1979. Phosphorus and its reactions in terrestrial soils and lake sediments. J. Scient. Agric. Soc. Finl. 51: 537-624.

HINGSTON, F. J., ATKINSON, R. J., POSNER, A. M. \& QUIRK, J. P. 1967. Specific adsorption of anions. Nature 215: 1459-1461.

KAILA, A. 1955. Studies on the colorimetric determination of phosphorus in soil extracts. Acta Agr. Fenn. 83: $25-47$.

- 1965. Effect of liming on the mobilization of soil phosphorus. J. Scient. Agric. Soc. Finl. 37: 243254.

KOUTLER-ANDERSSON, E. 1953. The sulfosalisylic acid method for iron determination and its use in certain soil analyses. Ann. R. Agric. Coll. Swed. 20: 297-301.

LI, W. C., ARMSTRONG, D. E., WILLIAMS, J. D. H., HARRIS, R. F. \& SYERS, J. K. 1972. Rate and extent of inorganic phosphate exchange in lake sediments. Soil Sci. Soc. Amer. Proc. 36: 279-285.

LINDSAY, W. L. \& MORENO, E. C. 1960. Phosphate equilibria in soils. Soil Sci. Soc. Amer. Proc. 24: $177-182$.

McLEAN, E. O. 1965. Aluminium. p. $978-998$ in Methods of soil analysis. II. Agronomy 9.

MORTLAND, M. M. 1968. Protonation of compounds at clay mineral surfaces. Trans. 9th Intern. Congr. Soil Sci. Adelaide. 1: 691-698.

PARKS, G. A. 1965. The isoelectric points of solid oxides, solid hydroxides and aqueous hydroxy complex systems. Chem. Rev. 65: 177-198.

RAJAN, S. S. S., PERROTT, K. W. \& SAUNDERS, W. M. H. 1974. Identification of phosphate-reactive sites of hydrous alumina from proton consumption during phosphate adsorption at constant $\mathrm{pH}$ values. J. Soil Sci. 25: 438-447.

SHUKLA, S. S., SYERS, J. K., WILliAMS, J. D. H., ARMSTRONG, D. E. \& HARRIS, R. F. 1971. Sorption of inorganic phosphate by lake sediments. Soil Sci. Soc. Amer. Proc. 35: 244-249.

SIPPOLA, J. \& JANSSON, H. 1979. Soil phosphorus test values obtained by acid ammonium acetate, water and resin extraction as predictors of phosphorus content in timothy (Pbleum pratense L.) Ann. Agric. Fenn. 18: 225-230.

STÅHLBERG, S. 1980. A new extraction method for estimation of plant available P, K, and Mg. An attempt at application to Swedish cultivated soils. Acta Agric. Scand. 30: 93-107.

TAMM, O. 1922. Eine methode zur Bestimmung der anorganischen Komponente des Gelkomplexes im Boden. Stat. Skogsförsöksanst. Medd. 19: 387-404. Stockholm.

WILLIAMS, J. D. H., SYERS, J. K., HARRIS, R. F. \& ARMSTRONG, D. E. 1971. Fractionation of inorganic phosphate in calcareous lake sediments. Soil Sci. Soc. Amer. Proc. 35: 250-255.

Ms received November 7, 1980 


\section{Happamuuden vähenemisen vaikutuksesta maan epäorgaanisen fosforin uuttuvuuteen}

\section{Helinä Hartikainen}

Helsingin yliopiston maanviljelyskemian laitos, 00710 Helsinki 71

Forforin uuttumista vesi- ja hartsimenetelmällä sekã maan fosforin reaktioita selvitettiin lyhytaikaisessa muhituskokeessa, jossa seitsemãn happaman kivennäismaanäytteen $\mathrm{pH}$ :ta nostettiin eriväkevyisillä $\mathrm{KOH}$-liuoksilla. Tuloksia vertailtiin pitkäaikaisessa kalkituskokeessa muhitettujen kivennäismaanäytteiden analyysituloksiin.

Sekã vesi- että hartsiuuttoisen fosforin määrä näytti lisääntyvän eksponenttiaalisesti $\mathrm{pH}$ :n funktiona. Hartsimenetelmällä saatiin suurempia uuttotuloksia, mutta maasuspension $\mathrm{pH}: \mathrm{n}$ kohotessa vesiliukoisen fosforin osuus hartsiuuttoisen fosforin määrästä kasvoi. Tämän katsottiin johtuvan $\mathrm{OH}^{*}$ ionien kasvavasta kilpailusta fosfaattiionien kanssa hartsin sorptiopaikoista.

CHANGIN ja JACKSONin fosforin fraktiointimenetelmällä saatujen tulosten perusteella pãäteltiin, että $\mathrm{pH}: \mathrm{n}$ muutoksiin reagoiva ja desorptioon osallistuva fosfori on pääasiassa peräisin sekundäärisistä $\mathrm{NH}_{4} \mathrm{~F}$ - ja $\mathrm{NaOH}$ - liukoisista varoista. Yleensä $\mathrm{NH}_{4} \mathrm{~F}-\mathrm{P}$ :n määrä kasvoi $\mathrm{NaOH}_{\mathrm{O}} \mathrm{P}$ :n kustannuksella happamuuden vähetessã. Voimakkaasti kalkitussa liejusavinäytteessä lisääntyi myōs $\mathrm{H}_{2} \mathrm{SO}_{4}-\mathrm{P}: \mathrm{n}$ määrä, mikä saattoi johtua mobilisoituneen fosforin saostumisesta Ca-yhdisteenä. Maasuspension $\mathrm{pH}$ :n merkitys fosforin uuttuvuuden kannalta näytti jonkin verran vähenevän maan sekundääristen P-varojen kasvaessa.

Tulokset tukevat käsitystä, jonka mukaan kalkitus voi parantaa epäorgaanisen fosforin kãyttökelpoisuutta ja vähentää P-lannoitustarvetta happamilla mailla. Maan $\mathrm{pH}: \mathrm{n}$ kohotessa lisääntyy kuitenkin riski, että eroosion mukana vesistöihin joutuvasta maa-aineksesta vapautuu fosforia veteen. Tãmän vuoksi voimakasta kalkitùsta tulisi välttää aivan rantojen lähistöllä. Järvien kalkituksesta saattaa myös aiheutua rehevöitymistä sedimenttien epäorgaanisen fosforin desorption lisääntyessä, mikä on otettava huomioon kalkitusta suunniteltaessa. 